ISSN 2078-6441. Вісник Львівського університету. Серія географічна. 2013. Випуск 42. С. 265-273. Visnyk of the Lviv University. Series Geography. 2013. Issue 42. P. 265-273.

$551.4(477.81)$

p c OB $\mathbf{K}$

ьвівський н ціон льний університет імені в н

вул. . орошенк , 41, 79000, м. ьвів, кр їн, e-mail:t.a.novak.lnu@gmail.com

$\mathrm{x}$ р ктеризов но геоморфологічну будову ізоцької височини $\mathrm{T}$ визн чено іiі місце в кл сифік ції форм рельєфу. ведено відмінності в геоморфологічній будові їі окремих ділянок. ро н лізов но геологічну і тектонічну зумовленість рельєфу ізоцької височини. исунуто припущення щодо ролі неотектонічних рухів у розвитку рельєфу височини.

лючові слов : ізоцьк височин, пл то, геологічн будов, горизонт льне розчленув ння, вертик льне розчленув ння, неотектонічні рухи.

ізоцьк височин $є$ однією із н йбільш гіпсометрично піднятих ділянок олинської височини. он з йм є іiї південно-східну ч стину і простяг ється вузьким п смом від м. убно до м. строг. ксим льн протяжність височини із з ходу н схід ст новить 50 км, із півночі н південь - 20 км. ередня протяжність ізоцької височини із з ходу н схід н ближ ється до м ксим льної, 3 півночі н південь колив ється в меж х 11-13 км (див. рис. 1). лощ височини ст новить $640 \mathrm{~km}^{2}$ [3].

кож ізоцьк височин відом під н звою хіднодубенської височини бо ізоцького кряжу [11, с. 128]. уже поширеним, особливо в фізико-геогр фічній н уковій літер турі, є топонім ізоцький кряж. н ш погляд, він не зовсім вд лий. гідно з “ етырехъязычным энциклопедическим слов рем терминов по физической геогр фии" . укін , кряж - це “удлинённ я, ч сто линейно вытянут я возвышенность с незн чительными и нер вномерными относительными высот ми; х р ктеризуется мягкими округлыми очерт ниями вершин” [12]. ут же уточнено, що, з звич й, кряжі є з лишк ми сильно зруйнов них і потім дещо піднятих у нед вньому геологічному минулому височин. ериторія ізоцької височини $є$ спр вді видовженою, хоч й не зовсім лінійно витягнутою. роте розподіл відносних висот досить рівномірний, з попр вкою н з г льний ухил території височини із північного з ходу н південний схід. крім того, вершини тут пр ктично не вир жені й злив ються у плоскі вершинні поверхні, рельєфові височини прит м нні озн ки пл то. кож сьогодні нем $є$ підст в ув ж ти ізоцьку височину з лишковим геологічним утворенням.

ещо інший підхід до визн чення ролі кряж в фізико-геогр фічній термінології $є$ в підручнику . имонов “ еоморфология”, де втор пропонує розгляд ти кряж як одну з л нок т ксономічного ряду форм рельєфу, протист вляючи його височині. оловною відмінністю кряж від височини, н думку . имонов , є його менш ізометричність. іншими морфометричними х р ктеристик ми кряж не дуже сильно відрізняється від височини [7, с. 28]. кож у з пропонов ній кл сифік ції елементів мезорельєфу . имонов н водить середні п р метри кряжів (відносне перевищення -

(C) ов к ., 2013 
270 м, ширин - 50 км, довжин - 320 км), спир ючись н ст тистичну вибірку н зв окремих форм рельєфу [7, с. 30]. р метри ізоцької височини зн чно поступ ються зг д ним вище, приблизно підп д ючи під п р метри ув лів згідно 3 цією кл сифік цією.

підст ві н ведених вище ргументів, н н шу думку, з погляду геоморфології коректнішим є вжив ння термін “височин” щодо досліджув ної ділянки.

ізоцьк височин $є$ скл довою т ксономічною одиницею різних схем геоморфологічного р йонув ння території кр їни. окрем, у пр ці . околовського вон н лежить до розчленов них денуд ційних структурних рівнин [8], . ись визн чив її як горбисту височину [11]. н ш погляд, н йповніше і н йоб'єктивніше визн чення, яке вр ховує всі основні морфологічні особливості височини, н ведене в схемі р йонув ння . лієнко т ін., де зг д н ділянк олинської височини н зв н

ізоцькою структурно-денуд ційною, пл топодібною, середньорозчленов ною височиною [4]. ижче ми дет льніше розглянемо й ргументуємо пр вомірність цих х р ктеристик.

р ктерною особливістю ізоцької височини є вир зність ії геоморфологічних меж. К з зн чено в моногр фії “рирод івненської обл сті” 3 ред кцією . еренчук, лише н сході ізоцьк височин не м є чітких орогр фічних меж і поступово переходить у лівий схил долини орині, злив ючись н північному сході 3 івненським пл то [6, с. 50]. івнічно-з хідний, з хідний і південний її кр ї вир жені чіткими уступ ми. ередні бсолютні висоти території ст новлять 290-300 м. йвищ точк є в з хідній ч стині височини, н північний схід від с. ірники. ї висот ст новить 342,6 м. ельєфові ізоцької височини прит м нний досить високий пок зник горизонт льного розчленув ння. . д нюк н лічує н її території 448 ярів т 6 лок [1]. устот горизонт льного розчленув ння зменшується в н прямі із з ходу н схід. либин вертик льного розчленув ння т кож м $€$ тенденцію до зниження в східному н прямі. ї м ксим льні зн чення не перевищують 50-60 м, що д ло змогу - лієнко зі спів втор ми з числити височину до середньорозчленов них [4].

опр вд, у н веденій кл сифік ції не вр хов но густоти горизонт льного розчленув ння. території ізоцької височини можн виділити кільк морфологічно однорідних р йонів.

хідн ч стин височини є гіпсометрично н йвищою. ередні бсолютні висоти тут колив ються в меж х 305-315 м. іпсометрично ділянк знижується у н прямі н південний схід. бсолютні позн чки вершинних поверхонь змінюються від 330-340 м н північному з ході до 300-310 м н південному сході. ериторія цієї ч стини ізоцької височини різко симетричн щодо вододільних ліній. оловний вододіл, який розділяє 6 сейни тиру і орині, проходить від південно-східної окр їни (с. ов

ощ ниця) через серію вершинних поверхонь н південь від долини р. битинк до н йвищої точки височини і м йже сяг є північно-з хідної іiі окр їни. ісля цього вододільн лінія різко змінює н прям із північно-з хідного н східний і виходить 3 межі височини поблизу с. ип . ериторії, які леж ть по різні боки вододілу, зн чно відрізняються інтенсивністю розчленув ння. ля ділянки, що н лежить до б сейну p. тир, х р ктерні зн чно глибші яри з порівняно крутішими схил ми т меншою довжиною. е можн пояснити вже зг д ною симетричністю ділянки, як зумовлює відмінності у положенні місцевого б зису ерозії ярів, який тут $є$ н окр їні височини. огляду н це переп д висот вершини і б зису ерозії ярів нерідко сяг є 55-60 м 


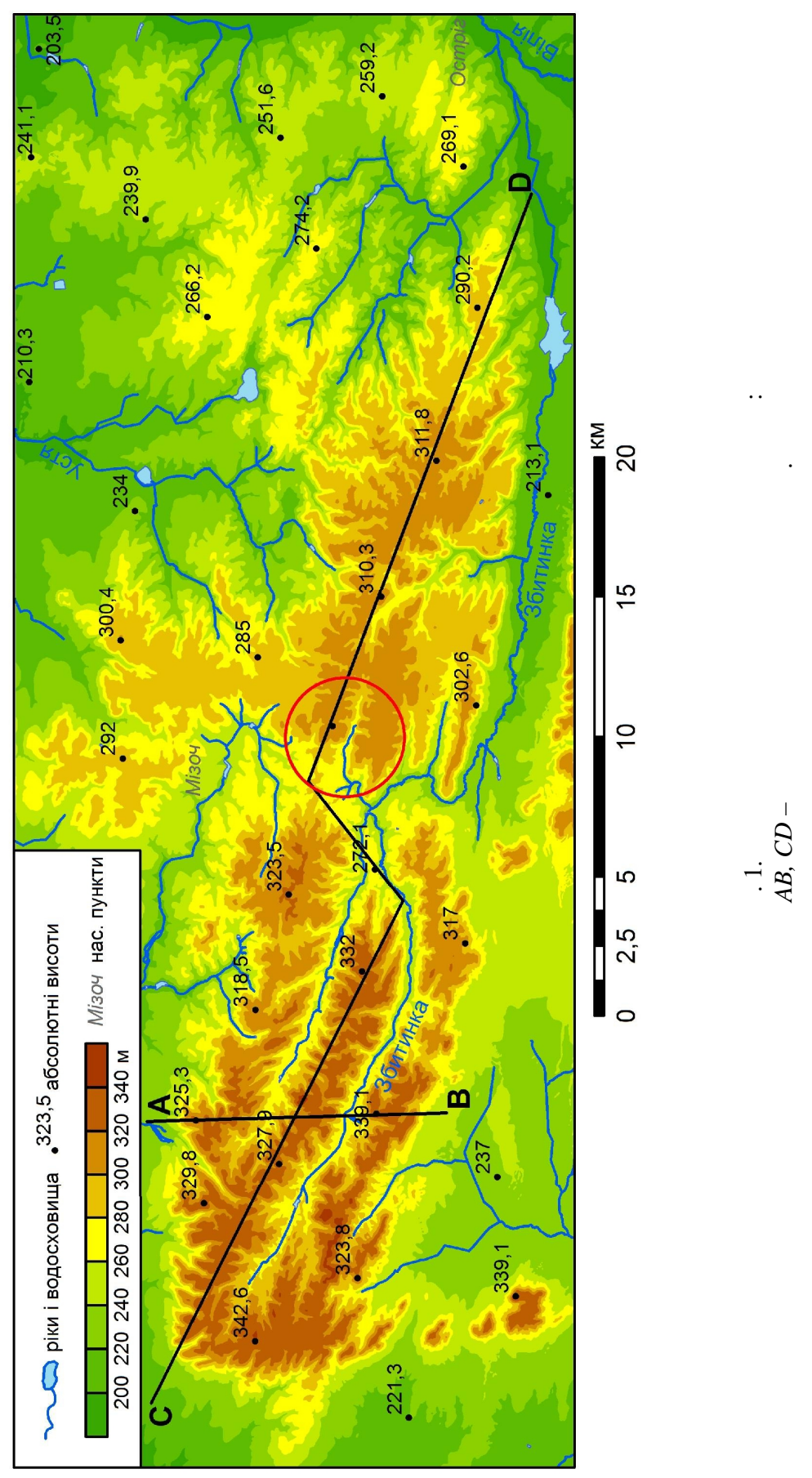




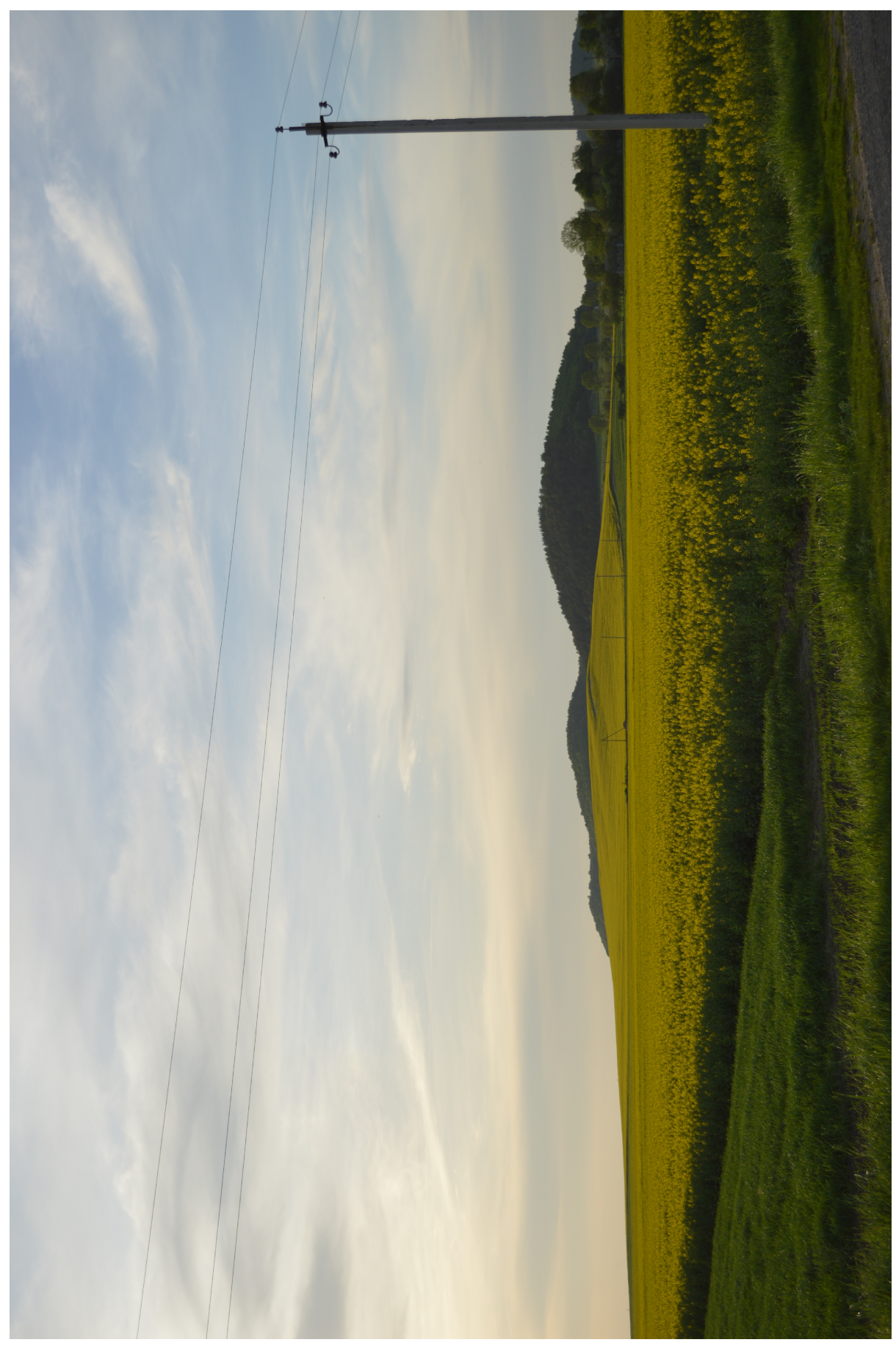

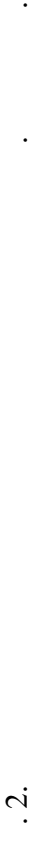


і більше. против гу цій ділянці, б зиси ерозії ярів 6 сейну орині є в долин х битинки, іщ нки т інших дрібніших водотоків. ідносно цих долин вони є субсеквентними і переп д висот вершини т б зису ерозії ярів зрідк перевищує 35-40 м.

кремо з зн чимо про ост нцеві горби, які простяг ються восьмикілометровою смугою 3 півночі $\mathrm{H}$ південь від південно-з хідної окр їни ізоцької височини (див. рис. 2). ут є шість чітко вир жених у рельєфі ост нцевих форм із різними розмір ми т пок зник ми бсолютних висот (н йвищою $є$ г. исок 3 бсолютною позн чкою 339,1 м). Г лом їхні висоти сумірні з середніми пок зник ми висот з хідної ч стини ізоцької височини. пільними озн к ми для цих ост нців є столов структур вершинних поверхонь т досить круті схили. ідносн висот горбівост нців н д довколишньою територією сяг є 100 м. втори звіту убенської геологознім льної п ртії ьвівської експедиції з $1959-1960$ рр. з зн чили про подібність

ізоцького і ременецького пл то й припустили, що ряд цих ост нців свідчить про безпосередній зв'язок ременецького і ізоцького пл то, який був порушений пізнішою денуд цією [10, с. 197]. кож близький до ост нцевого х р ктер м є південн ділянк 3 хідної ч стини ізоцької височини (від с. сенівк до с. ов ощ ниця).

ентр льно-східн ділянк ізоцької височини (від смт ізоч до с. ежиріч) досить чітко відокремлен від з хідної ділянки долин ми рік тубл і битинк т від північно-східної ділянки притокою р. битинк . к і для з хідної ділянки височини, для неї х р ктерний з г льний ухил поверхні у н прямі південного сходу. роте середні бсолюті висоти тут дещо нижчі і колив ються в меж х 290-295 м. відміну від східної ділянки, головний вододіл, який розділяє 6 сейни сті, тубли т битинки, проходить тут перев жно центр льною ч стиною території. е сприяє більшій однорідності ділянки з погляду інтенсивності розчленув ння. цій ч стині ізоцьк височин $\epsilon$ н йширшою в меридіон льному простяг нні. івнічні ії окр їни леж ть поблизу с. довбиця, де вон досить пл вно переходить в уцько- івненську височину. івденній межі ділянки, н відміну від північної, прит м нн більш вир зність. івденно-східн ч стин цієї ділянки м є клиноподібний вигляд і обр млен серією ост нців з порівняно невеликими відносними висот ми. кож з зн чимо, що долині однієї з приток р. битинк (виділен колом н рис. 1) вл стиве інверсійне з ляг ння. мовірно, це спричинено розломними порушеннями.

хідн ч стин ізоцької височини суттєво відрізняється від інших їі ділянок.

йголовніше, середні пок зники бсолютних висот тут ст новлять 250-255 м, що зн чно нижче, ніж н більшості території височини. кож, н відміну від інших ч стин, поверхня східної ділянки н хилен не в н прямі південного сходу, в н прямі північного сходу. оч структур поверхні ділянки зберіг є озн ки пл то (вирівняні плоскі вершинні поверхні, відносн піднятість н д довколишньою місцевістю), тут не простежується зн чних пок зників відносних висот, вершинні поверхні $€$ зн чно ширшими і менш розчленов ними. ля цієї ч стини височини х р ктерні порівняно мілкі яри з пологими схил ми і невеликою різницею висот вершини т 6 зису ерозії. ічкові долини ділянки м ють перев жний н прям із північного з ходу н південний схід, т кож озн ки з кл д ння вздовж розривних порушень. лежність цієї ділянки до ізоцької височини не є безз перечною. окрем, не вирішене пит ння щодо північно-східної межі височини.

днією із н йголовніших відмінностей ізоцької височини від усієї іншої території олинської височини є іiі пл топодібн структур . ізоцькій височині прит м нні основні озн ки пл то. “ етырехъязычном энциклопедическим слов ре терминов по 
физической геогр фии” термін “пл то” визн чено як “возвышенн я р внин с ровной или волнистой сл бо р счленённой поверхностью, огр ниченн я отчётливыми уступ ми от соседних более низких р внинных простр нств” [12]. к один із типів пл то в словнику розрізняють структурне пл то - “пл то, брониров нное горизонт льным стойким пл стом, выведенным н поверхность вследствие уд ления денуд цией леж вших выше, более под тливых пл стов” [12]. іднесення ізоцької височини н д довколишньою рівниною змінюється від 90-100 м у з хідній ч стині до 30-35 м у східній. к уже з зн чено вище, для більшості кр їв височини х р ктерні чіткі уступи. рис. 3, добре видно крутий і високий північний т дещо нижчий південний уступи. изн ч льну роль у формув нні пл топодібного рельєфу ізоцької височини відігр л н явність у геологічній структурі території в пнякової товщі, як виконує функцію бронюв льного ш ру. пняков товщ скл ден с рм тськими оолітовими і череп шковими в пняк ми, які н леж ть до волинських верств $\mathrm{N}_{1 \mathrm{vl}}$ [2]. ї сум рн потужність ст новить у середньому 10-12 м, зрідк сяг є $18 \mathrm{M.}$ явність цієї товщі в пняків сприял формув нню широких плоских вершинних поверхонь і зумовил особливості розвитку яркової ерозії. овщу неогенових в пняків перекрив $є$ лише м лопотужний (3-5 м у з хідній ч стині височини) ш р верхньочетвертинних еолово-делюві льних лесів [5], який не відігр є суттєвої ролі у формув нні з г льних рис рельєфу височини. о особливостей, які не х р ктерні для пл то, н лежить лише порівняно високий ступінь розчленов ності ізоцької височини. собливо добре вон вир жен в з хідній ч стині, як $є$ н йбільш піднятою і розбитою субп р лельними тектонічними розлом ми. ме до них приурочені долини рік битинки і іщ нки. ершинні поверхні тут дост тньо вузькі й сильно розчленов ні (див. рис. 3, ). орівняно м л потужність в пнякового пл ст, його тріщинув тість і підд тливість к рстовим процес м $\mathrm{p}$ зом із з г льною піднятістю території i різновіковими розривними порушеннями є сприятливими чинник ми для розвитку лінійної ерозії.

ур хув нням з зн чених структурно-геологічних т геоморфологічних особливостей ізоцької височини іiі можн з числити до типу структурно-денуд ційних пл топодібних, що й зроблено в кл сифік ції . лієнко т ін. [4].

жливу роль у формув нні рельєфу ізоцької височини відігр ли розривні порушення, головно неотектонічні. н чн їхня кількість ідентифіков н 3 допомогою глибинного буріння і дешифрув ння космознімків [9]. е виключено, що с ме процеси розтріскув ння і вертик льного переміщення блоків призвели до розбіжностей у гіпсометричному положенні й відповідно, у рельєфі різних ділянок височини. рис. 3, б чітко видно дв відокремлені блоки пл то, які відрізняються головно 3 бсолютними висот ми. н чення перев жних висот вершинних поверхонь блок (з хідн ч стин височини) в середньому н 20 м більші від н логічного пок зник блок (центр льно-східн ч стин височини). одноч с всередині одного блок вони різняться зн чно менше. бидв блоки розділені долин ми річок битинк i тубл т широкою б лкою, що поблизу с. унин, які, судячи з усього, узгоджені 3 тектонічним розломом субмеридіон льного н пряму. одібну ситу цію можн спостеріг ти і н межі центр льно-східної т східної ділянок височини.

ізоцьк височин простяг ється видовженою смугою вздовж південно-східної окр їни олинської височини. н уковій н н вч льній літер турі поширені кільк н зв цієї території, серед яких - ізоцький кряж, хіднодубенськ височин , ізоцьке пл то. ур хув нням існуючих критеріїв з числення форми рельєфу до типу кряжів, н голосимо, що ізоцьк височин не зовсім їм відповід $\epsilon$. ому, н н ш погляд, 
обгрунтов ність ужив ння термін “кряж” щодо ізоцької височини виклик є сумніви. йбільш об’єктивною є х р ктеристик височини як структурно-денуд ційної, пл топодібної, середньо розчленов ної [4].
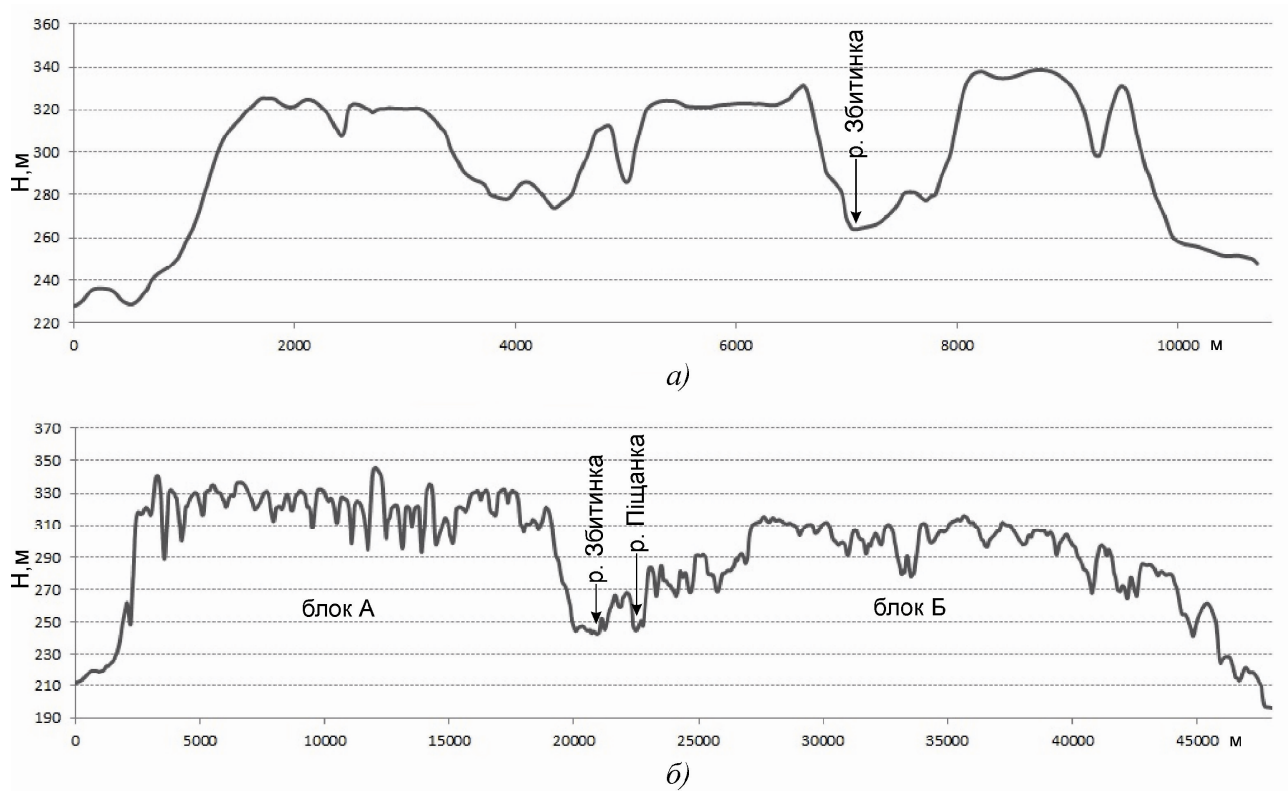

ис. 3. іпсометричні профілі через територію ізоцької височини.

г льний ухил рельєфу височини спрямов ний із північного з ходу н південний схід. йвищою є іiі з хідн ділянк (342,6 м). ельєфу височини вл стив досить сильн горизонт льн розчленов ність. собливо помітн вон в з хідній ч стині, де розвинен густ ярково-долинн мереж і поширені глибокі яри з урвистими схил ми.

хідн ділянк $є$ симетричною щодо головного вододілу, що зумовлює нерівномірну інтенсивність ерозійних процесів н цій території. о південно-з хідного кр ю височини примик є смуг із шести горбів-ост нців різного розміру, які м ють подібні до основної ч стини ізоцького пл то геологічну будову і морфологічні озн ки.

ентр льно-східн ділянк височини є гіпсометрично нижчою, ніж з хідн . й не прит м нн симетричність 3 хідної ділянки і вл стивий менш розчленов ний рельєф. ії меж $\mathrm{x}$ ізоцьк височин $є$ н йширшою у меридіон льному простяг нні. лежність східної ділянки до ізоцької височини виклик $€$ сумнів через ії порівняно низьке гіпсометричне положення, сл бку розчленов ність рельєфу і відсутність чітко вир женого північно-східного уступу. крім того, бронюв льний с рм тський в пняковий ш р не м є тут повсюдного поширення, н відміну від інших ч стин височини.

ізоцьк височин м є основні озн ки пл то, що зумовлено ії піднятістю і н явністю бронюв льного пл ст в пняків. дн к тут простежується не вл стив пл то дост тньо висок розчленов ність території, яку можн пояснити, н с мперед, сприятливістю в пняків до к рсту, н явністю серії розломів т з г льною піднятістю території. мовірно, розривні порушення т вертик льне переміщення блоків ст ли основною причиною відмінностей у гіпсометричному положенні вершинних поверхонь різних ч стин ізоцької височини. 
1. $\partial$ нюк . . орфометричний н ліз ярів ізоцького кряжу / . . д нюк // уковий вісник олин. н ціон льного ун-ту імені есі кр їнки. ер. геогр фія. 2009. - № 8 - . 25-30.

2. елінський . . роект н проведення робіт: “ еологічне довивчення м сшт бу 1:200000 т підготовк до вид ння комплекту ержгеолк рти-200 території ркуш M-35-XIV ( убно)”. - ., 2011.

3. ов льчук . . риродно-з повідний фонд території ізоцького кряжу: суч сний ст н, його к ртогр фічн модель, шляхи оптиміз ції функціонув ння / . . ов льчук, . . ндрейчук, . . д нюк // рирод хідного олісся т прилеглих територій. - уцьк, 2009. - № 9. - . 374-382.

4. лієнко . . г льне геоморфологічне р йонув ння території кр їни / . . лієнко, . . рщевський, . . ортник [т ін.] // кр. геогр. журн. 2004. - № 1. - . .3-11.

5. оліщук . . еотур “ еологічні об’єкти ізоцького кряжу” : [ лектронний pecypc] / . . оліщук, . . ельничук, . . ельничук. - ежим доступу: http://geomandry.com.ua.

6. рирод овенської обл сті / [3 ред. . . еренчук ]. - ьвів, 1976. - 156 с.

7. имонов . . еоморфология: методик фунд мент льных исследов ний / . . имонов. - . : зд-во оск. ун-т , 2005. - 427 с.

8. околовський. . еоморфологічн к рт з хідної ч стини / · околовський // еол. журн. - 1960 - . 20, вип. 4.

9. удовцев . . тчёт о проведении глубинного геологического к ртиров ния среднего (менее 1:200000) м сшт б территории лист M-35-XV ( овно) 3 1980-1984 гг. : в 7 т. / . . удовцев, . . теюк, . . ишняков [и др.]. овно, 1984.

10. женков . . еологическ я к рт лист M-35-XIV ( убно) / тчёт убновской геолого-съемочной п ртии ьвовской экспедиции з 1959-1960 гг. / . . женков, . . ер симов, . . естоп лов. - ., 1960. - н. 1. - 317 с.

11. $и с ь$. . еоморфологія / . . ись. - ьвів : ид-во ьвів. ун-ту, 1962. $224 \mathrm{c}$.

12. етырехъязычный энциклопедический слов рь терминов по физической геогр фии / [сост. . . укин]. - . . ов. энциклопедия, 1980. - 703 с. 


\title{
GENERAL CHARACTERISTICS OF GEOMORPHOLOGICAL STRUCTURE OF MIZOTS'KA UPLAND
}

\author{
Taras Novak \\ Ivan Franko National University of Lviv, \\ P. Doroshenko Str., 41, UA - 79000 Lviv, Ukraine, \\ e-mail: t.a.novak.lnu@gmail.com
}

Geomorphologic structure of Mizots'ka Upland and it place in a classification of landforms were described in the article. Description of the differences in geomorphologic structure between certain parts of the upland was provided. The impact of geology and tectonics on landforms of Mizots'ka Upland was analyzed and a hypothesis about the role of neotectonic movements in the development of its relief was put forward.

Keywords: Mizots'ka Upland, plateau, geologic structure, horizontal division, vertical division, neotectonic movements.

\section{p c $\mathbf{0 B} \mathbf{K}$}

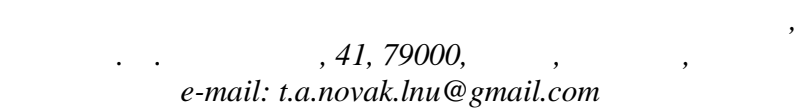

х $\mathrm{p}$ ктеризов но геоморфологическое строение изочской возвышенности и обозн чено её место в кл ссифик ции форм рельеф . риведено отличия в геоморфологическом строении её отдельных ч стей. ро н лизиров но геологическую и тектоническую обусловленность рельеф

изочской возвышенности. ыдвинуто предположение, к с ющееся роли неотектонических движений в р звитии рельеф возвышенности.

лючевые слов : изочск я возвышенность, пл то, геологическое строение, горизонт льн я p счлененность, вертик льн я р счлененность, неотектонические движения. 